\title{
ПРЕДПОСЫАКИ СУИЦИДАМЬНОГО ПОВЕДЕНИЯ У ДЕТЕЙ И ПОДРОСТКОВ КОРЕННЫХ НАРОДОВ СИБИРИ: КОГНИТИВНЫЕ ФАКТОРЫ РИСКА (ЧАСТЬ II)
}

\author{
Н.Б. Семёнова \\ ФГБНУ «Федеральный исследовательский центр «Красноярский научный центр Сибирского отделения \\ Российской академии наук", НИИ медицинских проблем Севера, г. Красноярск, Россия

\section{PREREQUISITES OF SUICIDAL BEHAVIOR IN CHILDREN AND ADOLESCENTS OF INDIGENOUS PEOPLES OF SIBERIA: COGNITIVE RISK FACTORS (PART II)}

N.B. Semenova Federal Research Centre "Krasnoyarsk Scientific Centre of Siberian Division of Russian Academy of Sciences, Scientific Research Institute for Medical Problems of the North, Krasnoyarsk, Russia

\section{Контактная информация:}

Семёнова Надежда Борисовна - доктор медицинских наук (SPIN-код: 8340-6208; ORCID iD: 0000-00022790-7740; Web of Science Researcher ID: M-5846-2019). Место работы и должность: главный научный сотрудник ФГБНУ «Федеральный исследовательский центр «Красноярский научный центр Сибирского отделения Российской академии наук", НИИ медицинских проблем Севера. Адрес: 660036, г. Красноярск, Академгородок, д. 50. Темефон: (913) 539-86-02, эмектронный адрес: snb237@gmail.com

Contact Information:

Mrs. Semenova Nadezhda Borisovna - Full Professor (Medicine). ORCID iD: 0000-0002-2790-7740; Web of Science Researcher ID: M-5846-2019; Researcher ID: U-4748-2017. Job Title: Head Scientific Worker of State Federal Budgetary Scientific Institution «Federal Research Centre «Krasnoyarsk Scientific Centre of Siberian Division of Russian Academy of Sciences", Scientific Research Institute for Medical Problems of the North, Krasnoyarsk, Russia. Postal Address: Akademgorodok, 50, Krasnoyarsk, 660036, Russia. Phone number: +7 91353986 02, E-mail: snb237@gmail.com

У подростков коренных народов Сибири выявлены когнитивные факторы риска суицидального поведения: дисфункциональные установки, склонность к чрезмерной генерализации, субъективное ощущение неразрешимости жизненных трудностей. Однако значение когнитивных факторов в формировании суицидального поведения не ограничивается искаженной когнитивной схемой, а охватывает более широкий спектр психических процессов. Цель исследования: изучить особенности когнитивных процессов у коренных популяций Сибири (якутов, эвенов, эвенков, алтайцев, агинских бурят и тувинцев), в сравнении с восточными славянами. Объект и методы исследования. Обследованы дети 9-10 лет, учащиеся общеобразовательных школ, проживающие в сельской местности, в национальных субъектах Российской Федерации, общей численностью 779 человек; из них якутов 180, эвенов и эвенков 49, алтайцев 135 , агинских бурят 154 , тувинцев 98 , восточных славян 163 человека. Средний возраст составил 9,8 лет. В исследовании использованы методики невербального плана: 1) Классификация картинок из теста Отиса-Леннона (OLSAT); 2) субтесты: Понятие последовательного порядка, Понятие горизонтальности и Понятие вертикальности из батареи рисуночных тестов Р. Силвера; 3 ) тест Рисунок человека в интерпретации А.Л. Венгера; 4) методики: Воспроизведение цифровых рядов, Кодирование из батареи невербальных субтестов Д. Векслера (WAIS, субтесты V и VII). Статистическая обработка полученных результатов проводилась с использованием пакета прикладных программ IBM SPSS Statistics, Version 22. Результаты. Становление интеллектуальных функций у представителей разных популяций происходит в соответствии с общими законами онтогенетического развития. Межпопуляционные различия, которые были выявлены, касались изобразительных навыков, показателей памяти, сформированности представлений о системе координат и скорости в обработке информации. У якутов, эвенов и эвенков лучше развита зрительная память (p<0,001), по сравнению со слухоречевой. У тувинцев лучше развита слухоречевая память, пространственное мышление и понятие о вертикали $(\mathrm{p}<0,001)$. У бурят лучше развито пространственное мышление и понимание горизонтали ( $\mathrm{p}=0,03)$. У алтайцев ниже показатели слухоречевой памяти $(\mathrm{p}=0,001)$. Данные различия мы объясняем спецификой образа жизни и основных видов деятельности, сформированных уникальными природными ландшафтами обитания. Главная особенность когнитивных процессов у коренных народов, в сравнении с восточными славянами, связана с разной скоростью обработки информации. При выполнении методики Кодирование якуты обработали 22,3 знака; эвенки и эвены - 16,1; алтайцы - 26,2; тувинцы $-26,4$; агинские буряты $-28,4$, что ниже, по сравнению с восточными славянами (30,6 знаков), $\mathbf{p}<0,001$. В ыв оды. У представителей коренных популяций Сибири, в сравнении с восточными славянами, выявлены культурно-специфические особенности когнитивных функций - сниженная скорость обработки информации, что мы расцениваем как фактор риска суицидального поведения, связанный с особенностями нейрокогнитивного функционирования.

Ключевые слова: этнопсихология, подростки, дети, психическое здоровье, суицид, коренные народы, Сибирь, факторы риска, нейрокогнитивные функции 
Наши предыдущие исследования показали, что у подростков коренных популяций Сибири чаще, чем у восточных славян, выявляются когнитивные факторы риска суицидального поведения - дисфункциональные установки, склонность к чрезмерной генерализации, субъективное ощущение неразрешимости жизненных трудностей. Однако значение когнитивных факторов в формировании суицидального поведения не ограничивается искажённой когнитивной схемой, а охватывает более широкий спектр психических процессов. Результаты растущего числа исследований указывают на ведущую роль нейрокогнитивного дефицита в процессе перехода от суицидальных мыслей к совершению самоубийства. C позиции нейрокогнитивной уязвимости суицидальное поведение объясняется нарушениями когнитивных исполнительных функций, в том числе, нарушениями внимания $[1,2]$, сниженной скоростью обработки информации [3], снижением когнитивной гибкости [4-7], недостаточностью когнитивного контроля [8-10], нарушениями вербальной беглости $[3,8$, $11,12]$ и рабочей памяти $[8,9,11]$. Показано, что существует наследственная передача особенностей нейрокогнитивного функционирования у суицидентов и их ближайших родственников $[13,14,15]$.

На сегодняшний день описаны некоторые механизмы, объясняющие причины суицидального поведения с позиции нейрокогнитивного дефицита. Показано, что нейрокогнитивные нарушения могут способствовать возникновению депрессивных расстройств, которые, в свою очередь, оказывают потенцирующее влияние на совершение самоубийства [14]. Выявлена связь дефицита распределения внимания с суицидальными идеациями через опосредованное влияние на нарушение регуляции эмоций $[16,17]$. Описана роль дефицита когнитивного контроля, приводящего к снижению способности к систематизации информации, необходимой для принятия решения [9, $10,18]$. Изучена ассоциация когнитивной гибкости с адаптационным ресурсом личности и влияние ригидности когнитивных установок на усиление стресса и фрустрации [8]. Показана связь ригидности когнитивных установок и сохранения суицидальных идеаций у подростков [19], что существенно повышает риск повторной суицидальной попытки.

На биологическом уровне суицидальное поведение объясняется нарушением функционирования двух различных анатомических систем, одна из которых лежит в основе когнитивного контроля и связана с дорсолатеральными префронтальными областями, а другая несёт ответственность за процесс принятия решений и связана с вентральной префронтальной корой [9]. Предполагается, что нарушение когнитивных исполнительных функций, связанное с дорсолатеральными префронтальными областями, играет основную роль в совершении законченного суицида, а первичный мотивационный тормозной путь, связанный с орбитофронталь-
Our previous studies have shown that adolescents of indigenous populations of Siberia are inclined to have cognitive risk factors for suicidal behavior - dysfunctional attitudes, a tendency to excessive generalization, and a subjective feeling of inability to overcome life difficulties - more often than eastern Slavs. However, the importance of cognitive factors in the formation of suicidal behavior is not limited to a distorted cognitive scheme. It is believed to cover a wider range of mental processes. The results of a growing number of studies indicate the leading role of neurocognitive deficit in the transition from suicidal thoughts to committing suicide. From the position of neurocognitive vulnerability, suicidal behavior is explained by impaired cognitive executive functions, including impaired attention [1,2], reduced processing speed [3], decreased cognitive flexibility [4-7], insufficient cognitive control [8-10], violations of verbal fluency $[3,8,11,12]$ and working memory $[8,9,11]$. It has been shown that there are hereditary traits of the features of neurocognitive functioning in suicide attempters and their closest relatives [13, 14, 15].

To date, several mechanisms have been described that explain the causes of suicidal behavior from the point of neurocognitive deficiency. It has been shown that neurocognitive impairment can contribute to the development of depressive disorders, which, in turn, have a potentiating effect on suicide [14]. The relationship between attention deficit and suicidal ideation through an indirect effect on the dysregulation of emotions was revealed [16, 17]. The role of cognitive deficit is described, which leads to a decrease in the ability to systematize the information necessary for decision-making $[9,10$, 18]. The association of cognitive flexibility with the adaptive resource of the personality and the effect of rigidity of cognitive attitudes on increasing stress and frustration were studied [8]. The connection between rigidity of cognitive attitudes and the preservation of suicidal ideation in adolescents has been shown [19], which significantly increases the risk of repeated suicidal attempts.

At the biological level, suicidal behavior is explained by the malfunctioning of two different anatomical systems, one of which is the basis of cognitive control and is associated with the dorsolateral prefrontal areas, and the other is responsible for the decision-making process and is associated with the ventral prefrontal cortex [9]. It is assumed that the violation of cognitive executive functions associated with the dorsolateral prefrontal areas plays a major role in committing suicide, and the primary motivational inhibitory path associated with the orbitofrontal cortex, including conflicting, affective and reflective decision-making processes, underlies repeated self-harm of a non-suicidal nature [12]. 
ной корой, включающий конфликтные, аффективные и рефлексивные процессы принятия решений, лежит в основе повторяющихся самоповреждений несуицидального характера [12].

В одном из последних исследований по изучению структур нейрональных связей головного мозга методом визуализации с помощью МРТ - трактографии были выявлены изменения в корковых и подкорковых областях головного мозга у лиц, совершивших суицидальную попытку, на основе чего была предложена гипотеза сетевого диатеза к суицидальному поведению [20]. Хотя взаимосвязи между структурными и функциональными нарушениями до сих пор не ясны, полученные результаты позволяют предположить зависимость функциональных нарушений от дефицита серого и белого вещества, что может привести к неадаптивным когнитивным процессам, ассоциациированным с суицидальным поведением.

Вышеперечисленные факты указывают на необходимость исследования не только психических состояний, лежащих на поверхности изучаемого явления, но и устойчивых особенностей психики. Знание проксимальных и дистальных факторов, а также динамической природы их потенциального взаимодействия является необходимым условием для понимания механизмов формирования суицидального поведения и концептуализации его рисков [21]. Именно такой подход лежит в основе современных моделей суицидального поведения $[22,23]$.

Мы выдвинули научную гипотезу о том, что у коренных популяций Сибири имеются этнические особенности психических процессов, создающие когнитивную уязвимость к суицидальному поведению.

Цель исследования: изучить особенности когнитивных процессов у коренных народов Сибири, в сравнении с восточными славянами.

Дизайн исследования.

Обследованы дети 9-10 лет, учащиеся общеобразовательных школ, проживающие в сельской местности национальных субъектов РФ - Республике Саха (Якутия), Республике Алтай, Агинском Бурятском округе и Республике Тыва. Всего обследовано 779 человек, из них, якутов 180 , эвенов и эвенков 49, алтайцев 135 , агинских бурят 154 , тувинцев 98 , восточных славян 163 человека. Средний возраст составил 9,8 лет.

Применялись методики невербального плана, свободные от влияния культуры и языка, так как для коренных народов Сибири русский язык не является родным [24].

Изучение операционального интеллекта проводилось с использованием субтеста Классификация картинок из элементарного уровня серии тестов школьных достижений Отиса-Леннона (OLSAT) для учащихся младшего школьного возраста [25]. Школьникам раздавались бланки с изображенными на них 11 рядами картинок (по 5 картинок в ряду) и
In one of the latest studies on the structure of brain neuronal connections by using MRI tractography, changes were revealed in the cortical and subcortical regions of the brain in individuals who made a suicidal attempt, on the basis of which the hypothesis of network diathesis to suicidal behavior was proposed [20]. Although the relationship between structural and functional disorders is still not clear, the results suggest a dependence of functional disorders on the deficit of gray and white matter, which can lead to non-adaptive cognitive processes associated with suicidal behavior.

The above mentioned facts indicate the need to study not only mental states lying on the surface of the phenomenon under study, but also the stable characteristics of the psyche. Knowledge of proximal and distal factors, as well as the dynamic nature of their potential interaction, is a prerequisite for understanding the mechanisms of formation of suicidal behavior and conceptualizing its risks [21]. It is this approach that underlies modern models of suicidal behavior [22, 23].

We hypothesize that the indigenous populations of Siberia have ethnic characteristics of mental processes that create a cognitive vulnerability to suicidal behavior.

The aim of the study is to analyze the characteristics of cognitive processes in the indigenous peoples of Siberia, in comparison with the Eastern Slavs.

Study design. The children of 9-10 years of age, the students of secondary schools living in rural areas of the national constituent entities of the Russian Federation - the Republic of Sakha (Yakutia), the Republic of Altai, the Aginsky Buryat District and the Republic of Tyva were examined. A total of 779 people were examined, including 180 Yakuts, 49 Evens and Evenks, 135 Altai, 154 Agin Buryats, 98 Tuvinians, 163 Slavs from the East. The mean age was 9.8 y.o.

We used non-verbal methods, free from the influence of culture and language, since Russian is not native for the indigenous peoples of Siberia [24].

The study of operational intelligence was carried out using the subtest Classification of pictures from the elementary level of the OtisLennon School Ability Test (OLSAT) for students of primary school age [25]. Schoolchildren were given forms with 11 rows of pictures depicted on them (5 pictures in a row) and were asked to cross out one picture in each row that does not fit the others. The result was calculated by the sum of the total number of correct answers (from 1 to 11 points).

To assess the level of formation of spatial thinking and the degree of development of ideas about the coordinate system (horizontal or vertical), the subtest task for predicting from the 
предлагалось вычеркнуть одну картинку в каждом ряду, как неподходящую к остальным. Результат подсчитывался по сумме общего количества правильных ответов (от 1 до 11 баллов).

Для оценки уровня сформированности пространственного мышления и степени развития представлений о системе координат (горизонтальность / вертикальность) применялся субтест Задание на прогнозирование из батареи рисуночных тестов Р. Силвера [26]. Субтест включает в себя три задания, при выполнении которых учащимся предлагалось изобразить уровень лимонада в постепенно пустеющем стакане (понятие последовательного порядка), уровень воды в наклоненной бутылке (понятие горизонтальности) и нарисовать домик на крутом склоне горы (понятие вертикальности). Оценка результатов проводилась по шкале от 0 до 5 баллов, отдельно по каждому заданию, после чего вычислялась сумма баллов по всем трем заданиям.

Уровень развития изобразительных навыков оценивался с использованием методики Рисунок человека в интерпретации А.Л. Венгера [27]. В основе методики лежат закономерности изображения человека в зависимости от возраста ребёнка. Количественная оценка результатов проводилась путём подсчёта баллов, полученных за выполнение числа основных и второстепенных деталей (от 4 до 30 баллов).

Изучение механической памяти проведено с использованием методики Воспроизведение цифровых рядов из батареи невербальных субтестов Д. Векслера (WISC-III - Wechsler, 1991). Школьникам предлагалось прослушать ряд цифр, запомнить его, а затем воспроизвести в письменном виде. Цифровые ряды предъявлялись в прямом и обратном порядке, с каждым разом происходило увеличение количества цифр на одну. Результаты фиксировались по общему количеству воспроизведённых цифр в правильном порядке в прямом и обратном предъявлениях.

Для исследования скорости обработки информации применялась методика Кодирование из батареи невербальных субтестов Д. Векслера (WISC-III Wechsler, 1991). За ограниченный отрезок времени (в данном случае за 90 сек.) учащимся предлагалось заполнить клеточки в таблице путём написания под каждой цифрой соответствующий ей знак. Оценивалось количество правильно выполненных знаков, одновременно фиксировалось количество ошибок.

Анализ полученных результатов мы проводили в два этапа. На первом этапе определялся общий уровень развития познавательных способностей у представителей всех популяций. Для определения степени сформированности аналитико-синтетической функции мышления проведён качественный анализ теста Классификация картинок (OLSAT): результат 10-11 баллов оценивался как высокий, 6-9 баллов средний, 5 баллов и менее - низкий. Для определения battery of R. Silver's picture tests was used [26]. The subtest includes three tasks in which students were asked to depict the level of lemonade in a gradually empty glass (the concept of sequential order), the water level in a tilted bottle (the concept of horizontalness) and draw a house on a steep mountainside (the concept of verticality). Evaluation of the results was carried out on a scale from 0 to 5 points, separately for each task, after which the total points for all three tasks were calculated.

The level of development of drawing skills was evaluated using the method of drawing a man in the interpretation of A.L. Wenger [27]. The methodology is based on the laws of the image of a person depending on the age of a child. A quantitative assessment of the results was carried out by calculating the points obtained for fulfilling the number of primary and secondary details (from 4 to 30 points).

The study of mechanical memory was carried out using the method of Reproduction of digital series from a battery of non-verbal subtests by D. Wechsler (WISC - III - Wechsler, 1991). Students were encouraged to listen to a series of numbers, memorize the series, and reproduce it in writing. Digital series were presented in the direct and reverse order, each time there was an increase in the number of digits by one. The results were recorded by the total number of reproduced numbers in the correct order in the forward and reverse presentations.

To study the speed of information processing, we used the method of Encoding from a battery of non-verbal subtests by D. Wechsler (WISC - III - Wechsler, 1991). For a limited time period (in our case, for 90 seconds), students were asked to fill in the cells in the table by writing the corresponding sign for each digit. The number of correctly written characters was estimated, and the number of errors was recorded as well.

We analyzed the results in two stages. At the first stage, the general level of development of cognitive abilities in representatives of all populations was determined. To determine the degree of formation of the analytical and synthetic thinking function, a qualitative analysis of the Image Classification Test (OLSAT) was carried out: the result of 10-11 points was rated as high, 6-9 points - as medium, 5 points and less - as low. To determine the degree of mastery of the logical rules, a qualitative analysis of the performance of the subtest was carried out. The concept of sequential order (from the Silver's test battery): a result of 4-5 points was rated as high, 2-3 points as medium, 0-1 points as low.

At the second stage, the data were analyzed from the position of ethnic differences: the results obtained from children of the indigenous 
степени овладения логическими правилами проведён качественный анализ выполнения субтеста Понятие последовательного порядка (из батареи теста Силвера): результат 4-5 баллов оценивался как высокий, 2-3 балла - средний, 0-1 балл - низкий.

На втором этапе данные анализировались с позиции этнических различий: результаты, полученные у детей коренного населения, сравнивались с результатами восточных славян, проживающих в идентичных условиях, обучающихся по идентичным учебным программам, в школьных классах совместно с детьми коренного населения. Было сформировано 7 групп: якуты (группа 1); эвены и эвенки (группа 2); русские, проживающих на севере Сибири, в Республике Саха (группа 3); алтайцы (группа 4); буряты (группа 5); тувинцы (группа 6); русские, проживающие на юге Сибири, в Республике Алтай (группа 7). Учитывая, что северные и южные районы Сибири отличаются по географическим и климатическим условиям, что влияет на скорость протекания психических процессов, сравнение показателей проводилось с учётом вышеперечисленных обстоятельств: показатели школьников, проживающих в северных (группы 1, 2 и 3) и южных районах (группы 4, 5, 6 и 7), сравнивались отдельно.

При интерпретации полученных результатов мы придерживались универсалистской теоретической ориентации в области этнопсихологии, согласно которой все культуры имеют как универсальные (этические), так и культурно - специфические (эмические) элементы [28]. Ориентиром для оценки когнитивных функций явилась концепция интеллектуального развития Ж. Пиаже, согласно которой все психические функции рассматриваются с позиции их отношения к интеллекту [29].

Статистическая обработка полученных результатов проводилась с использованием пакета прикладных программ IBM SPSS Statistics, Version 22. Тип распределения определялся с помощью критериев Шапиро - Уилка и Колмогорова - Смирнова. Описание количественных данных, имеющих нормальное распределение, проводилось с использованием среднего арифметического (М) и 95\% доверительного интервала (CI). Для сравнения средних значений в трёх и более независимых группах применялся однофакторный дисперсионный анализ (ANOVA) с дальнейшим апостериорным попарным сравнением с помощью критерия Бонферрони. Описание количественных данных при распределении, отличном от нормального, проводилось с использованием медианы $(\mathrm{Me})$ и нижнего и верхнего квартилей $\left(\mathrm{Q}_{1}-\mathrm{Q}_{3}\right)$. Для сравнения трёх и более независимых групп применялся непараметрический критерий Краскела - Уоллиса с дальнейшим попарным сравнением с использованием критерия Манна - Уитни. Величина уровня значимости различий (р) принималась при $\mathrm{p}=0,05$, то есть при ошибке $5 \%$. population were compared with the results of the East Slavs living in identical conditions, learning under the same curriculum, in the same school classes, together with children of the indigenous population. 7 groups were formed: Yakuts (group 1); Evens and Evenks (group 2); Russians living in the north of Siberia in the Republic of Sakha (group 3); Altai people (group 4); Buryats (group 5); Tuvans (group 6); Russians living in southern Siberia in the Republic of Altai (group 7). Given that the northern and southern regions of Siberia differ in geographical and climatic conditions, which affects the rate of mental processes, a comparison of the indicators was carried out taking into account the above circumstances: indicators of students living in the northern (groups 1,2 and 3 ) and southern regions (groups 4, 5, 6 and 7), were compared separately.

When interpreting the results, we followed a universalist theoretical orientation in the field of ethnopsychology, according to which all cultures have both universal (ethical) and culturally specific (emic) elements [28]. A reference point for evaluating cognitive functions was J. Piaget's concept of intellectual development, according to which all mental functions are considered from the perspective of their relationship to intelligence [29].

Statistical processing of the results was carried out using the IBM SPSS Statistics, Version 22 application package. The distribution type was determined using the Shapiro-Wilk and Kolmogorov-Smirnov criteria. Quantitative data with a normal distribution were described using the arithmetic average (M) and $95 \%$ confidence interval (CI). To compare the mean values in three or more independent groups, one-way analysis of variance (ANOVA) was used, followed by a posteriori pairwise comparison using the Bonferroni test. Quantitative data were described for a distribution other than normal using the median (Me) and the lower and upper quartiles (Q1-Q3). To compare three or more independent groups, the non-parametric Kruskal-Wallis test was used with further pairwise comparison using the Mann-Whitney criterion. The value of the significance level of differences ( $p$ ) was taken at $\mathrm{p}=0.05$, i.e. with an error of $5 \%$.

Results.

Figure 1 shows that the majority of students at the age of 9-10 perform the Image Classification Test at an average level, with an assessment of 6 to 9 points: $51.9 \%$ Yakuts, $53.1 \%$ Evens and Evenks, $57.0 \%$ Altai, $76.3 \%$ of Tuvans, $46.5 \%$ of Eastern Slavs living in the Republic of Sakha (Yakutia) and 52.6\% in the Republic of Altai. The exception is the Agin Buryats, most of whom showed slightly higher results (58.4\%). 


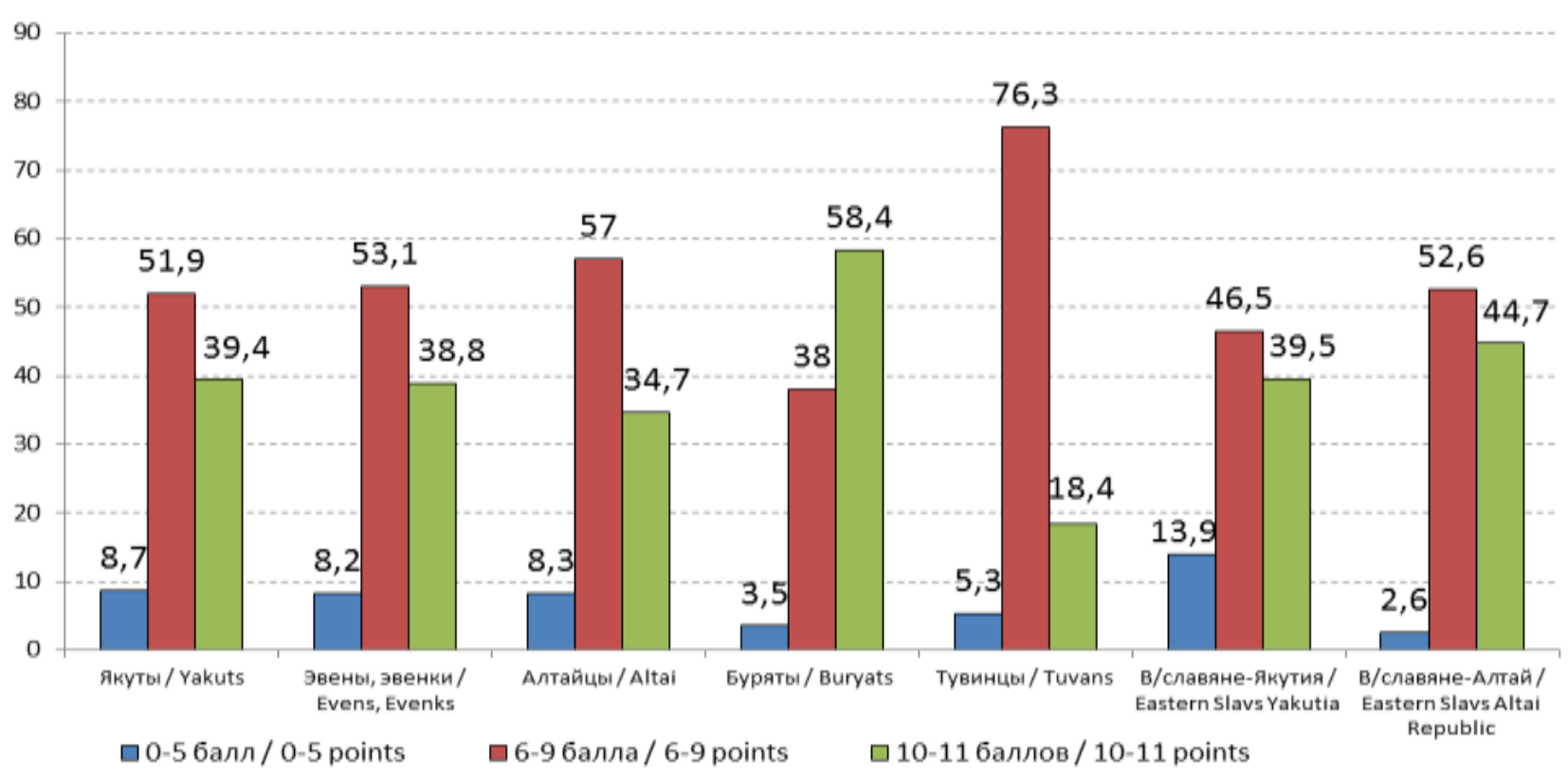

Puc. 1 / Fig. 1. Результаты выполнения теста Классификация картинок (\%) / Results for completing the Image Classification subtest (\%).

Результаты исследования.

Качественный анализ выполнения психологических тестов представителями разных популяций Сибири представлен на рис. 1-2.

Из рисунка 1 видно, что большинство учащихся в 9-10-летнем возрасте выполняют тест Классификация картинок на среднем уровне, с оценкой от 6 до 9 баллов: $51,9 \%$ якутов, 53,1\% эвенов и эвенков, 57,0\% алтайцев, 76,3\% тувинцев, 46,5\% восточных славян, проживающих в Республике Саха (Якутия) и 52,6\% в Республике Алтай. Исключение составляют агинские буряты, большинство которых показали более высокие результаты $(58,4 \%)$.
Figure 2 shows that most students at the age of 9-10 cope with the Sequential Order Concept subtest. $73.9 \%$ of Yakuts, $65.3 \%$ of Evens and Evenks, $67.4 \%$ of Altaians, $73.7 \%$ of Buryats, $92.1 \%$ of Tuvans, $64.4 \%$ of East Slavs living in the Republic Sakha (Yakutia) and $82.2 \%$ of the Eastern Slavs living in the Altai Republic received 4-5 points for completing the task. These results indicate that in students of all populations the development and functioning of the main mental processes goes along with the stage of specific operations that is characterized by the manipulation of symbols, the mastery of mental operations and logical rules.

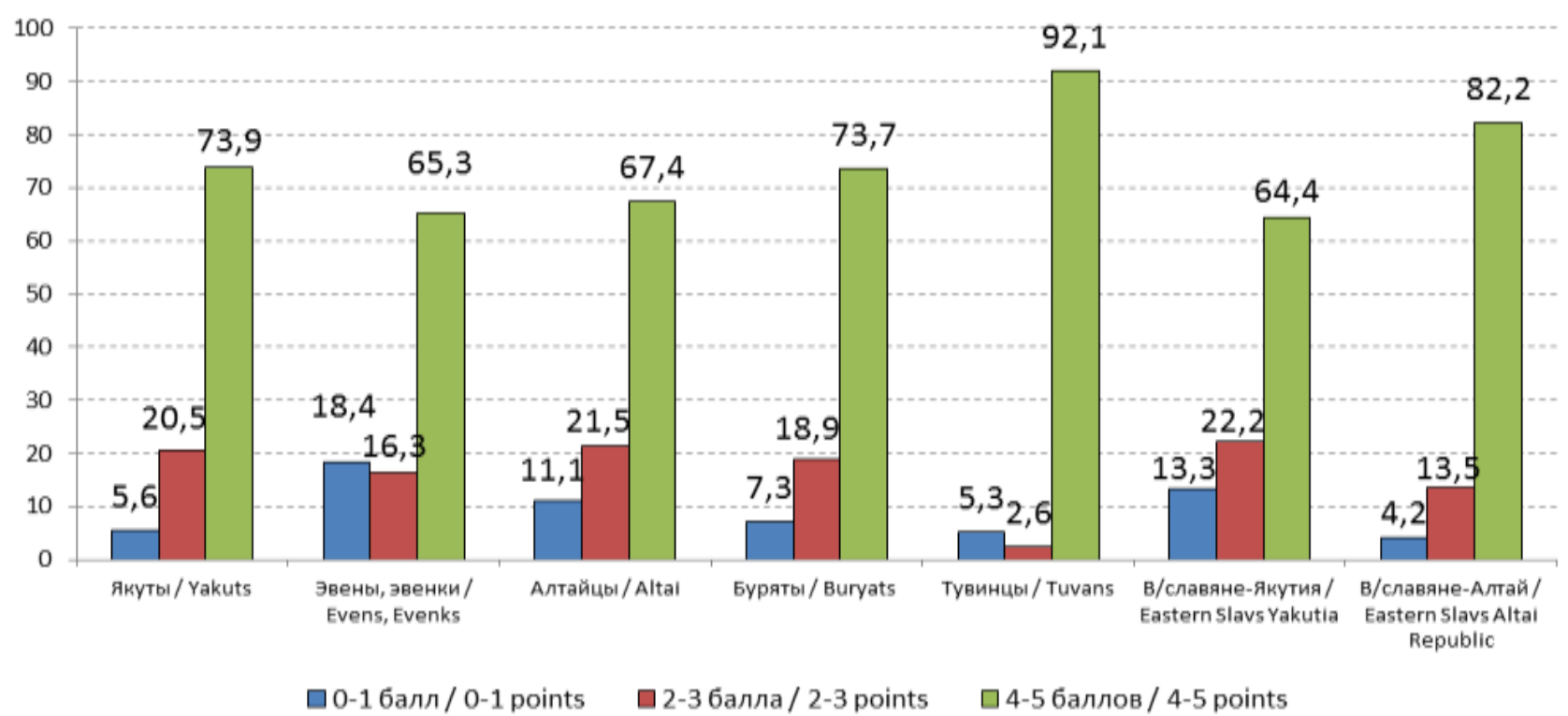

Puc. 2 / Fig. 2. Результаты выполнения субтеста Понятие последовательного порядка (\%) / Results of completing the Sequential Order Concept subtest (\%). 
На рисунке 2 можно отметить, что большинство учащихся в 9-10-летнем возрасте справляются с субтестом Понятие последовательного порядка. Получили 4-5 баллов за выполнение задания 73,9\% якутов, $65,3 \%$ эвенов и эвенков, $67,4 \%$ алтайцев, $73,7 \%$ бурят, 92,1\% тувинцев, $64,4 \%$ восточных славян, проживающих в Республике Саха (Якутия) и $82,2 \%$ восточных славян, проживающих в Республике Алтай. Данные результаты свидетельствуют в пользу того, что у школьников всех популяций функционирование основных мыслительных процессов соответствует стадии конкретных операций, для которой характерно манипулирование символами, овладение мыслительными операциями и логическими правилами.

Количественный анализ выполнения психологических тестов представителями разных популяций Сибири представлен в таблице 1.

При сравнении данных, полученных у школьников, проживающих в северных районах Сибири, с применением критерия Краскела-Уоллиса, выявлены различия для теста Венгера $(\mathrm{H}=21,13, \mathrm{df}=2, \mathrm{p}<0,001)$. Дальнейшее попарное сравнение методом МаннаУитни показало, что у коренных народов Сибири, проживающих в северных районах, лучше развиты изобразительные навыки, по сравнению с восточными славянами, что подтверждается более высокими результатами выполнения рисуночных методик у якутов $(\mathrm{U}=2434,5, \mathrm{Z}=-3,55, \mathrm{p}<0,001)$, эвенов и эвенков $(\mathrm{U}=2434,5, \mathrm{Z}=-3,55, \mathrm{p}<0,001)$.

The quantitative analysis of the performance of psychological tests by representatives of different populations of Siberia is presented in table 1. When comparing the data obtained from schoolchildren living in the northern regions of Siberia using the Kruskal-Wallis test, differences were found for the Wenger test $(\mathrm{H}=21.13, \mathrm{df}=2, \mathrm{p}<0.001)$. Further pairwise comparison by the Mann-Whitney method showed that the indigenous peoples of Siberia living in the northern regions have better developed visual skills compared to the Eastern Slavs, which is confirmed by higher results in performing drawing techniques in the Yakuts $(\mathrm{U}=2434.5, \mathrm{Z}=-3.55, \mathrm{p}<0.001)$, Evens and $\mathrm{Ev}$ enks $(U=2434.5, Z=-3.55, p<0.001)$.

For schoolchildren living in the southern regions of Siberia, differences were obtained for the OLSAT test $(\mathrm{H}=45.22, \mathrm{df}=3, \mathrm{p}<0.001)$, Sequential Order Concept subtest $(\mathrm{H}=30.11$, $\mathrm{df}=2, \mathrm{p}<0.001)$, Horizontality Concept subtest $(\mathrm{H}=48.60, \mathrm{df}=2, \mathrm{p}<0.001)$, Verticality Concept subtest $(\mathrm{H}=28.22, \mathrm{df}=2, \mathrm{p}<0.001)$, the overall result of the Silver test $(\mathrm{H}=45.1, \mathrm{df}=2, \mathrm{p}<0.001)$ and Wenger test $(\mathrm{H}=8.79, \mathrm{df}=2, \mathrm{p}=0.03)$. Further pairwise comparison by the Mann-Whitney method showed heterogeneous results. So, the Agin Buryats, in comparison with the rest, coped better with the Horizontality Concept subtest ( $U=6858.00, Z=-2.15, p=0.03$ ). The Altai people had lower performance than the Eastern Slavs when performing the OLSAT methodology $(\mathrm{U}=5480.50, \mathrm{Z}=-2.76, \mathrm{p}=0.006)$ subtests.

Таблица 1 / Table 1

Показатели выполнения психологических тестов представителями разных популяций Сибири $\left(\mathrm{Me}_{\mathrm{e}} \mathrm{Q}_{1}-\mathrm{Q}_{3}\right)$

Performance indicators of psychological tests by representatives of different populations of Siberia (Me, Q1-Q3)

\begin{tabular}{|c|c|c|c|c|c|c|c|c|c|c|c|c|}
\hline & $\begin{array}{c}\text { Гp. } 1 \\
\text { Group } 1\end{array}$ & \begin{tabular}{|c|} 
एр. 2 \\
Group 2
\end{tabular} & \begin{tabular}{|c|} 
Гp. 3 \\
Group 3
\end{tabular} & $\begin{array}{c}\text { Гp. } 4 \\
\text { Group } 4\end{array}$ & $\begin{array}{c}\text { Гр. } 5 \\
\text { Group } 5\end{array}$ & $\begin{array}{c}\text { Гp. } 6 \\
\text { Group } 6\end{array}$ & \begin{tabular}{c|} 
Гp. 7 \\
Group 7
\end{tabular} & \multicolumn{5}{|c|}{$p$} \\
\hline $\begin{array}{c}\text { Методика } \\
\text { Test }\end{array}$ & $\begin{array}{l}\text { Якуты } \\
\text { Yakuts } \\
(n=180)\end{array}$ & $\begin{array}{c}\text { Эвены, } \\
\text { эвенки } \\
\text { Evens, } \\
\text { Evenks } \\
(\mathrm{n}=49)\end{array}$ & $\begin{array}{c}\text { Алтайцы } \\
\text { Altais } \\
(n=135)\end{array}$ & $\begin{array}{l}\text { Буряты } \\
\text { Buryats } \\
(\mathrm{n}=154)\end{array}$ & $\begin{array}{c}\text { Tувинцы } \\
\text { Tuvans } \\
(n=98)\end{array}$ & $\begin{array}{c}\text { славяне / } \\
\text { Якутия } \\
\text { Eastern } \\
\text { Slavs / } \\
\text { Yakut } \\
(\mathrm{n}=45)\end{array}$ & $\begin{array}{c}\text { славяне } \\
\text { / Алтай } \\
\text { Eastern } \\
\text { Slavs / } \\
\text { Altai } \\
(n=118)\end{array}$ & $1-6$ & $2-6$ & $3-7$ & $4-7$ & $5-7$ \\
\hline $\begin{array}{l}\text { Классификация картинок } \\
\text { Picture Classification Test } \\
(\text { OLSAT) }\end{array}$ & $\begin{array}{c}9,0 \\
(7,0-9,0)\end{array}$ & $\begin{array}{c}9,0 \\
(7,5-10,0)\end{array}$ & $\begin{array}{c}9,0 \\
(7,0-10,0)\end{array}$ & $\begin{array}{c}10,0 \\
(8,0-11,0)\end{array}$ & $\begin{array}{c}8,0 \\
(7,0-9,0)\end{array}$ & $\begin{array}{c}9,0 \\
(7,0-10,0)\end{array}$ & $\begin{array}{c}9,0 \\
(8,0-10,0)\end{array}$ & & & 0,006 & & $*$ \\
\hline $\begin{array}{l}\text { а) понятие последовательно- } \\
\text { го порядка } \\
\text { Sequential Order Concept }\end{array}$ & $\begin{array}{c}4,0 \\
(3,0-5,0)\end{array}$ & $\begin{array}{c}5,0 \\
(3,0-5,0)\end{array}$ & $\begin{array}{c}4,0 \\
(3,0-5,0)\end{array}$ & $\begin{array}{c}5,0 \\
(3,0-5,0)\end{array}$ & $\begin{array}{c}5,0 \\
(5,0-5,0)\end{array}$ & $\begin{array}{c}4,0 \\
(3,0-5,0)\end{array}$ & $\begin{array}{c}5,0 \\
(4,0-5,0)\end{array}$ & & & 0,02 & & $*$ \\
\hline $\begin{array}{l}\text { б) понятие горизонтальности } \\
\text { Horizontalness Concept }\end{array}$ & $\begin{array}{c}4,0 \\
(2,0-5,0)\end{array}$ & $\begin{array}{c}4,0 \\
(2,0-5,0)\end{array}$ & $\begin{array}{c}2,0 \\
(1,0-4,0)\end{array}$ & $\begin{array}{c}4,0 \\
(3,0-5,0)\end{array}$ & $\begin{array}{c}4,0 \\
(2,0-5,0)\end{array}$ & $\begin{array}{c}3,0 \\
(1,0-5,0)\end{array}$ & $\begin{array}{c}3,0 \\
(1,0-5,0)\end{array}$ & & & $*$ & 0,03 & \\
\hline $\begin{array}{l}\text { в) понятие вертикальности } \\
\text { Verticality Concept }\end{array}$ & 2,0 & 3,0 & 3,0 & 2,0 & 3,0 & 2,0 & 3,0 & & & & & $*$ \\
\hline г) общий балл & $\begin{array}{c}(1,0-5,0) \\
10,0\end{array}$ & $\begin{array}{c}(1,0-5,0) \\
10,0\end{array}$ & $\begin{array}{c}(1,0-5,0) \\
9,0\end{array}$ & $\begin{array}{c}(1,0-5,0) \\
10,0\end{array}$ & $\begin{array}{c}(3,0-4,0) \\
12,0\end{array}$ & $\begin{array}{c}(1,0-3,0) \\
9,0\end{array}$ & $\begin{array}{c}(1,0-3,0) \\
10,0\end{array}$ & & & 0,001 & & $*$ \\
\hline Total & $(8,0-11,0)$ & $(7,0-12,0)$ & $(7,0-11,0)$ & $(8,0-12,0)$ & $(10,0-13,0)$ & $(7,0-11,0)$ & $(8,0-12,0)$ & & & & & \\
\hline $\begin{array}{l}\text { Рисунок человека (Венгер) } \\
\text { A Drawing of a Man (Wenger) }\end{array}$ & $\begin{array}{c}22,0 \\
(20,0-23,0)\end{array}$ & $\begin{array}{l}23,0 \\
(21,0- \\
23,0)\end{array}$ & $\begin{array}{c}24,0 \\
(22,0-26,0)\end{array}$ & $\begin{array}{c}23,0 \\
(21,0-26,0)\end{array}$ & $\begin{array}{c}24,0 \\
(22,0-26,0)\end{array}$ & $\begin{array}{c}20,0 \\
(19,0-21,0)\end{array}$ & $\begin{array}{l}24,0 \\
(22,0- \\
26,0)\end{array}$ & * & * & & & \\
\hline
\end{tabular}

$* \mathrm{P}<0,001 ;$ 
У школьников, проживающих в южных районах Сибири, различия были получены для теста OLSAT $(\mathrm{H}=45,22, \mathrm{df}=3, \mathrm{p}<0,001)$, субтестов Понятие последовательного порядка $(\mathrm{H}=30,11, \mathrm{df}=2, \mathrm{p}<0,001)$, Понятие горизонтальности $(\mathrm{H}=48,60, \mathrm{df}=2, \mathrm{p}<0,001)$, Понятие вертикальности $(\mathrm{H}=28,22, \mathrm{df}=2, \mathrm{p}<0,001)$, общего результата теста Силвера $(\mathrm{H}=45,1, \mathrm{df}=2, \mathrm{p}<0,001)$ и теста Венгера $(\mathrm{H}=8,79, \mathrm{df}=2, \mathrm{p}=0,03)$. Дальнейшее попарное сравнение методом Манна-Уитни показало неоднородные результаты. Так, агинские буряты, по сравнению с остальными, лучше справились с субтестом Понятие горизонтальности $(\mathrm{U}=6858,00, \mathrm{Z}=-2,15$, $\mathrm{p}=0,03)$. У алтайцев результативность выполнения заданий оказалась ниже, чем у восточных славян, при выполнении методики OLSAT (U=5480,50, $\mathrm{Z}=-2,76$, $\mathrm{p}=0,006)$, субтестов Понятие последовательного порядка (U=6742,50, $\mathrm{Z}=-2,30, \mathrm{p}=0,02)$ и Понятие горизонтальности (U=5691,50, $\mathrm{Z}=-4,04, \quad \mathrm{p}<0,001)$, что определило более низкий результат теста Силвера ( $\mathrm{U}=6128,50, \mathrm{Z}=-3,18, \mathrm{p}=0,001)$. Что касается тувинцев, то по сравнению с восточными славянами они хуже справились с тестом OLSAT (U=2542,00, $\mathrm{Z}=-4,90$, $\mathrm{p}<0,001)$, а пространственные тесты выполнили лучше: Понятие последовательного порядка ( $\mathrm{U}=3370,50$, $\mathrm{Z}=-3,59, \quad \mathrm{p}<0,001), \quad$ Понятие вертикальности $(\mathrm{U}=2846,00, \mathrm{Z}=-4,57, \mathrm{p}<0,001)$, что определило более высокий результат теста Силвера ( $U=2974,50, Z=-$ $3,98, \mathrm{p}<0,001)$.

Показатели памяти и умственной работоспособности у представителей разных популяций Сибири представлены в таблице 2.
The Sequential Order Concept $(\mathrm{U}=6742.50, \mathrm{Z}=-2.30, \mathrm{p}=0.02)$ and the Horizontality Concept $(\mathrm{U}=5691.50, \quad \mathrm{Z}=-4.04$, $\mathrm{p}<0.001)$ subtests determined a lower Silver test result $(\mathrm{U}=6128.50, \mathrm{Z}=-3.18, \mathrm{p}=0.001)$. As for the Tuvans, compared to the Eastern Slavs, they performed worse with the OLSAT test $(\mathrm{U}=2542.00, \mathrm{Z}=-4.90, \mathrm{p}<0.001)$, and they performed better on spatial tests: The Sequential Order Concept $(\mathrm{U}=3370 . \quad 50, \quad \mathrm{Z}=-3.59$, $\mathrm{p}<0.001)$, the Verticality Concept $(\mathrm{U}=2846.00$, $Z=-4.57, p<0.001)$ determined a higher Silver test result $(\mathrm{U}=2974.50, \mathrm{Z}=-3.98, \mathrm{p}<0.001)$.

Indicators of memory and mental performance in representatives of different populations of Siberia are presented in table 2. When comparing the average data on memory and mental performance of indigenous children with the Eastern Slavs by the method of ANOVA, differences were obtained for auditory-verbal memory $(\mathrm{F} 2,264=7.51, \mathrm{p}=0.001)$ and general mental performance $(\mathrm{F} 2.261=61.75, \mathrm{p}<0.001)$. Further a posteriori comparison showed that the volume of auditory-verbal memory in the Yakuts, Evens, Evenks and Altai was lower compared to the Eastern Slavs. In particular, the storage of numbers in direct presentation is lower for Yakuts by an average of 0.5 characters ( $\mathrm{SD}=0.93, \mathrm{t}=-3.669, \mathrm{df}=216, \mathrm{p}=0.001)$, for Evens and Evenks by 0.5 characters $(\mathrm{SD}=0.71$, $\mathrm{t}=-3.181, \mathrm{df}=90, \mathrm{p}=0.001)$, Altai people have 0.5 digits $(\mathrm{SD}=0.58, \mathrm{t}=-6.188, \mathrm{df}=242$, $\mathrm{p}=0.001)$

Показатели памяти и умственной работоспособности у представителей разных популяций Сибири (M, 95\% CI) Indicators of memory and mental performance in representatives of different populations of Siberia (M, 95\% CI)

\begin{tabular}{|c|c|c|c|c|c|c|c|c|c|c|c|c|}
\hline & $\begin{array}{c}\text { Гp. } 1 \\
\text { Group } 1\end{array}$ & $\begin{array}{c}\text { Гр. } 2 \\
\text { Group } 2\end{array}$ & $\begin{array}{c}\text { Гp. } 3 \\
\text { Group } 3\end{array}$ & $\begin{array}{c}\text { Гр. } 4 \\
\text { Group } 4\end{array}$ & $\begin{array}{c}\text { Гр. } 5 \\
\text { Group } 5\end{array}$ & $\begin{array}{c}\text { Гp. } 6 \\
\text { Group } 6\end{array}$ & $\begin{array}{c}\text { Гр. } 7 \\
\text { Group } 7\end{array}$ & \multicolumn{5}{|c|}{$p$} \\
\hline $\begin{array}{c}\text { Методика } \\
\text { Test }\end{array}$ & $\begin{array}{l}\text { Якуты } \\
\text { Yakuts } \\
(n=180)\end{array}$ & $\begin{array}{l}\text { Эвены, } \\
\text { эвенки } \\
\text { Evens, } \\
\text { Evenks } \\
(n=49)\end{array}$ & $\begin{array}{l}\text { Алтайцы } \\
\text { Altais } \\
(\mathrm{n}=135)\end{array}$ & $\begin{array}{l}\text { Буряты } \\
\text { Buryats } \\
(n=154)\end{array}$ & $\begin{array}{c}\text { Тувинцы } \\
\text { Tuvans } \\
(\mathrm{n}=98)\end{array}$ & $\begin{array}{l}\text { славяне / } \\
\text { Якутия } \\
\text { Eastern } \\
\text { Slavs / } \\
\text { Yakut } \\
(\mathrm{n}=45)\end{array}$ & \begin{tabular}{|} 
славяне / \\
Алтай \\
Eastern \\
Slavs / \\
Altai \\
$(\mathrm{n}=118)$
\end{tabular} & $1-6$ & $2-6$ & $3-7$ & $4-7$ & $5-7$ \\
\hline $\begin{array}{l}\text { Запоминание uцифр } \\
\text { Memorizing figures }\end{array}$ & & & & & & & & & & & & \\
\hline $\begin{array}{l}\text { a) прямое предъявление } \\
\text { direct presentation }\end{array}$ & $\begin{array}{c}3,9 \\
(3,7-4,1)\end{array}$ & $\begin{array}{c}4,0 \\
(3,7-4,3)\end{array}$ & $\begin{array}{c}3,9 \\
(3,8-4,0)\end{array}$ & $\begin{array}{c}4,3 \\
(4,1-4,5)\end{array}$ & $\begin{array}{c}4,9 \\
(4,7-5,1)\end{array}$ & $\begin{array}{c}4,6 \\
(4,4-4,9)\end{array}$ & $\begin{array}{c}4,5 \\
(4,3-4,6)\end{array}$ & $* *$ & 0,01 & $* *$ & & $*$ \\
\hline $\begin{array}{l}\text { б) обратное предъявле- } \\
\text { ние / reverse presentation }\end{array}$ & $\begin{array}{c}3,1 \\
(2,9-3,3)\end{array}$ & $\begin{array}{c}3,1 \\
(2,9-3,3)\end{array}$ & $\begin{array}{c}2,8 \\
(2,6-2,9)\end{array}$ & $\begin{array}{c}3,8 \\
(3,4-4,1)\end{array}$ & $\begin{array}{c}3,8 \\
(3,5-4,0)\end{array}$ & $\begin{array}{c}3,3 \\
(2,9-3,7)\end{array}$ & $\begin{array}{c}3,3 \\
(3,1-3,6)\end{array}$ & & & $* * *$ & & 0,006 \\
\hline $\begin{array}{l}\text { в) общий показатель } \\
\text { total result } \\
\text { Кодирование / Coding }\end{array}$ & $\begin{array}{c}7,0 \\
(6,7-7,3)\end{array}$ & $\begin{array}{c}7,1 \\
(6,7-7,5)\end{array}$ & $\begin{array}{c}6,7 \\
(6,5-6,9)\end{array}$ & $\begin{array}{c}8,1 \\
(7,6-8,5)\end{array}$ & $\begin{array}{c}8,7 \\
(8,4-9,0)\end{array}$ & $\begin{array}{c}7,9 \\
(7,5-8,4)\end{array}$ & $\begin{array}{c}7,8 \\
(7,5-8,2)\end{array}$ & 0,01 & & * & & $*$ \\
\hline $\begin{array}{l}\text { а) количество обработан- } \\
\text { ных знаков / the number } \\
\text { of symbols processed }\end{array}$ & $\begin{array}{c}22,3 \\
(21,2-23,4)\end{array}$ & $\begin{array}{c}16,1 \\
(15,1-17,1)\end{array}$ & $\begin{array}{c}26,2 \\
(24,8-27,7)\end{array}$ & $\begin{array}{c}28,4 \\
(27,1-29,7)\end{array}$ & $\begin{array}{c}26,4 \\
(24,4-28,3)\end{array}$ & $\begin{array}{c}29,3 \\
(27,9-30,8)\end{array}$ & $\begin{array}{c}30,6 \\
(29,4-31,8)\end{array}$ & $*$ & $*$ & $* *$ & 0,03 & 0,003 \\
\hline $\begin{array}{l}\text { б) количество ошибок } \\
\text { the number of errors }\end{array}$ & $\begin{array}{c}0,7 \\
(0,3-1,2)\end{array}$ & $\begin{array}{c}0,2 \\
(0,0-0,3)\end{array}$ & $\begin{array}{c}0,9 \\
(0,4-1,4)\end{array}$ & $\begin{array}{c}0,4 \\
(0,08-0,7)\end{array}$ & $\begin{array}{c}0,6 \\
(0,2-0,9)\end{array}$ & $\begin{array}{c}0,3 \\
(0,1-0,7)\end{array}$ & $\begin{array}{c}0,6 \\
(0,05-1,2)\end{array}$ & & & & & \\
\hline
\end{tabular}

$* \mathrm{P}<0,001 ; * * \mathrm{P}=0,001 ; * * * \mathrm{P}=0,02$ 
При сравнении средних значений памяти и умственной работоспособности у детей коренных популяций, в сравнении с восточными славянами, методом однофакторного дисперсионного анализа (ANOVA) получены различия для слухоречевого запоминания $\left(\mathrm{F}_{2,264}=7,51\right.$, $\mathrm{p}=0,001)$ и умственной работоспособности $\left(\mathrm{F}_{2,261}=61,75\right.$, $\mathrm{p}<0,001)$. Дальнейшее апостериорное сравнение показало, что объем слухоречевой памяти у якутов, эвенов, эвенков и алтайцев оказался ниже, по сравнению с результатами, полученными у восточных славян. В том числе, объём запоминания цифр в прямом предъявлении меньше у якутов в среднем на 0,5 знака $(\mathrm{SD}=0,93, \mathrm{t}=-$ $3,669, \mathrm{df}=216, \mathrm{p}=0,001)$, у эвенов и эвенков на 0,5 знака $(\mathrm{SD}=0,71, \mathrm{t}=-3,181, \mathrm{df}=90, \mathrm{p}=0,001)$, у алтайцев на 0,5 знака $(\mathrm{SD}=0,58, \mathrm{t}=-6,188, \mathrm{df}=242, \mathrm{p}=0,001)$. Объём запоминания цифр в обратном предъявлении меньше у алтайцев в среднем на 0,5 знака $(\mathrm{SD}=1,08, \mathrm{t}=-3,651$, $\mathrm{df}=242, \mathrm{p}=0,002)$. Общий объём запоминания меньше у якутов в среднем на 0,7 знака $(\mathrm{SD}=1,63, \mathrm{t}=-2,776, \mathrm{df}=217$, $\mathrm{p}=0,01)$, у алтайцев на 1,1 знака $(\mathrm{SD}=1,22, \mathrm{t}=-5,681$, $\mathrm{df}=242, \mathrm{p}<0,001)$. Показатели слухо-речевой памяти у тувинцев, проживающих в сельской местности, оказались выше, чем у восточных славян: объём запоминания цифр в прямом предъявлении у тувинцев в среднем на 1,4 знака больше $(\mathrm{SD}=1,94, \mathrm{t}=7,064, \mathrm{df}=212, \mathrm{p}<0,001)$, в обратном - на 0,5 знака $(\mathrm{SD}=1,12, \mathrm{t}=3,266, \mathrm{df}=212$, $\mathrm{p}=0,006)$, общий объём запоминания больше в среднем на 0,9 знака $(\mathrm{SD}=1,49, \mathrm{t}=3,846, \mathrm{df}=212, \mathrm{p}<0,001)$.

Показатели умственной работоспособности по результатам методики Кодирование у представителей всех коренных популяций оказались ниже, в сравнении с восточными славянами. Так, за определённый отрезок времени якуты обработали меньше в среднем на 6,5 знака ( $\mathrm{SD}=6,49, \mathrm{t}=-6,296, \mathrm{df}=217, \mathrm{p}<0,001)$, эвенки и эвены на 13,2 знаков ( $\mathrm{SD}=3,49, \mathrm{t}=-15,347, \mathrm{df}=90$, $\mathrm{p}<0,001)$, алтайцы на 4,1 знака ( $\mathrm{SD}=8,51, \mathrm{t}=-4,195$, $\mathrm{df}=250, \mathrm{p}=0,001)$, тувинцы на 3,9 знака $(\mathrm{SD}=9,75, \mathrm{t}=-$ $3,513, \mathrm{df}=213, \mathrm{p}=0,003)$, агинские буряты на 1,9 знака $(\mathrm{SD}=7,71, \mathrm{t}=-2,1, \mathrm{df}=257, \mathrm{p}=0,03)$.

Обсуждение результатов.

Согласно концепции интеллектуального развития Ж. Пиаже [29], младший школьный возраст, к которому принадлежат обследованные дети, относится к периоду становления репрезентативного интеллекта и формирования способности к конкретным операциям. Интеллектуальндые функции в этом возрасте проявляются как в виде простых операций (классификация, взаимно однозначное соответствие), так и системы операций (система координат, проективные понятия). Анализ выполнения методик представителями разных этнических групп показал, что у большинства школьников в возрасте 9-10 лет формируется способность к анализу, синтезу и логическому мышлению, что подтверждается результатами выполнения субтестов Классификация картинок и Понятие последовательного порядка. Данный факт позволяет придти к выводу о том,
The amount of memorization of numbers in the reverse presentation is lower for the Altai people by an average of 0.5 characters $(\mathrm{SD}=1.08, \mathrm{t}=-3.651, \mathrm{df}=242, \mathrm{p}=0.002)$. The total memory volume is less in Yakuts by an average of 0.7 characters $(\mathrm{SD}=1.63, \mathrm{t}=-2.776$, $\mathrm{df}=217, \mathrm{p}=0.01)$, among Altai people by 1.1 characters $\quad(\mathrm{SD}=1.22, \mathrm{t}=5.681, \quad \mathrm{df}=242$, $\mathrm{p}<0.001)$. The indicators of auditory-verbal memory among Tuvans living in rural areas were higher than among the Eastern Slavs: the amount of numbers memorized in direct presentation by Tuvans is on average 1.4 more $(\mathrm{SD}=1.94, \mathrm{t}=7.064, \mathrm{df}=212, \mathrm{p}<0.001)$, in the opposite - by 0.5 digits $(\mathrm{SD}=1.12, \mathrm{t}=3.266$, $\mathrm{df}=212, \mathrm{p}=0.006$ ), the total amount of memorization is higher by an average of 0.9 characters $(\mathrm{SD}=1,49, \mathrm{t}=3.846, \mathrm{df}=212, \mathrm{p}<0.001)$.

Indicators of mental performance according to the results of the Coding technique for representatives of all indigenous populations were lower in comparison to the Eastern Slavs. So, for a certain period of time, the Yakuts processed an average of 6.5 characters less ( $\mathrm{SD}=6.49, \mathrm{t}=-6.296, \mathrm{df}=217, \mathrm{p}<0.001), \mathrm{Ev}-$ enks and Evens were 13.2 characters behind $(\mathrm{SD}=3,49, \mathrm{t}=-15.347, \mathrm{df}=90, \mathrm{p}<0.001)$, Altai people -4.1 characters $(\mathrm{SD}=8.51, \mathrm{t}=-4.195$, $\mathrm{df}=250, \mathrm{p}=0.001)$, Tuvans -3.9 characters $(\mathrm{SD}=9.75, \mathrm{t}=-3.513, \mathrm{df}=213, \mathrm{p}=0.003)$, Agin Buryats - 1.9 digits, $(\mathrm{SD}=7.71, \mathrm{t}=-2.1$, $\mathrm{df}=257, \mathrm{p}=0,03)$.

The discussion of the results.

According to the concept of intellectual development by J. Piaget [29], the primary school age, of which the children examined are, is the period of the formation of representative intelligence and the formation of the ability to perform specific operations. Intellectual functions at this age are manifested both in the form of simple operations (classification, one-to-one correspondence), and systems of operations (coordinate system, projective concepts). Analysis of the implementation of methods by representatives of different ethnic groups showed that most students aged 9-10 have the ability to analyze, synthesize and think logically, which is confirmed by the results of the Classification of Pictures and the Sequential Order Concept subtests. This fact allows to conclude that the formation of basic mental processes in schoolchildren of the studied populations corresponds to the stage of specific operations, which is characterized by the manipulation of symbols, the mastery of mental operations and logical rules [29], and the formation of intellectual functions in accordance with the general laws of ontogenetic development.

The main differences that we have identi- 
что у школьников обследованных популяций становление основных мыслительных процессов соответствует стадии конкретных операций, для которой характерно манипулирование символами, овладение мыслительными операциями и логическими правилами [29], а становление интеллектуальных функций происходит в соответствии с общими законами онтогенетического развития.

Основные различия, которые мы выявили у представителей разных этносов, касаются изобразительных навыков, показателей памяти, сформированности представлений о системе координат и скорости в обработке информации. Так, у представителей коренных популяций, проживающих в северных районах Сибири, выявлено лучшее развитие сенсорной, или зрительной памяти, по сравнению со слухоречевой, что подтверждается более высокой результативностью выполнения рисуночных методик $(p<0,001)$ и сниженной продуктивностью запоминания цифр $(\mathrm{p}<0,05)$. Это не противоречит современным данным о функциональной разобщённости вербальной и сенсорной памяти в области дорсолатеральной префронтальной коры [30].

При обследовании представителей коренных популяций, проживающих в южных районах Сибири, получены неоднородные результаты. Так, у тувинцев, по сравнению с восточными славянами, позже формируется аналитико-синтетическая функция мышления, что подтверждается меньшей результативностью теста OLSAT ( $<<001)$, однако у них лучше развита слухоречевая память (запоминание цифр), пространственное мышление и представления о системе координат, в частности, понятие о вертикали $(\mathrm{p}<0,001)$. У алтайцев менее развита слухоречевая память $(\mathrm{p}=0,001)$, позже формируются аналитико - синтетическая функция $(\mathrm{p}=0,006)$ и пространственное мышление $(\mathrm{p}=0,001) . \mathrm{У}$ бурят, по сравнению с восточными славянами, раньше начинает формироваться аналитико-синтетическая функция мышления $(\mathrm{p}=0,006)$ и лучше развито пространственное мышление, в частности, понимание горизонтали $(\mathrm{p}=0,03)$.

Особенности психических процессов у представителей коренных популяций мы объясняем разными экологическими условиями проживания (северные и южные районы Сибири), различиями ландшафта (тундра, лесотундра, степная или горно-степная зона), спецификой традиционного образа жизни и ведущих видов деятельности, что закрепляло те психические функции, которые были необходимы для более успешной адаптации. Бескрайние северные просторы и образ жизни охотников и рыболовов стимулировал у якутов, эвенов и эвенков лучшее развитие сенсорной или зрительной памяти [31, 32]. Горно-степной ландшафт и традиционный образ жизни кочевников-скотоводов стимулировал развитие у тувинцев пространственного мышления и понимание принципов устойчивости на наклонной плоскости, в частности, восприятие вертикальной поверхности [33]. fied among representatives of different ethnic groups relate to visual skills, memory indicators, the formation of ideas about the coordinate system and speed in processing information. Thus, representatives of indigenous populations living in the northern regions of Siberia showed a better development of sensory and visual memory compared to auditory and verbal memory, which is confirmed by a higher performance of drawing techniques $(\mathrm{p}<0.001)$, and reduced productivity of memorizing numbers $(p<0.05)$. This does not contradict modern data on the functional disunity of verbal and sensory memory in the dorsolateral prefrontal cortex [30].

When examining representatives of indigenous populations living in the southern regions of Siberia, heterogeneous results were obtained. So, Tuvans, in comparison to the Eastern Slavs, tend to form analyticalsynthetic function of thinking later, which is confirmed by the lower efficiency of the OLSAT test $(\mathrm{p}<0.001)$, but they have better developed auditory-verbal memory (memorization of numbers), spatial thinking and ideas about the coordinate system and the concept of verticality in particular $(\mathrm{p}<0.001)$. Altai people have less developed auditory-verbal memory $(p=0.001)$, tend to form analyticalsynthetic function $(\mathrm{p}=0.006)$ and spatial thinking $(\mathrm{p}=0.001)$ later. The Buryats in comparison to the Eastern Slavs began to form analytical-synthetic function of thinking $(\mathrm{p}=0.006)$ and spatial thinking earlier and better have them developed, especially, horizontal understanding $(\mathrm{p}=0.03)$.

We believe the peculiarities of mental processes in representatives of indigenous populations are caused by different environmental living conditions (northern and southern regions of Siberia), differences in landscape (tundra, forest-tundra, steppe or mountain-steppe zone), the specifics of the traditional way of life and leading activities that reinforced mental functions that were necessary for more successful adaptation. The endless northern landscapes and lifestyle of hunters and fishermen in Yakuts, Evens, and Evenks stimulated a better development of sensory or visual memory $[31,32]$. The mountainsteppe landscape and the traditional way of life of nomadic herders encouraged the development of spatial thinking among Tuvans and an understanding of the principles of stability on an incline, the perception of a vertical surface in particular [33]. The economic structure of the steppe nomads formed the idea of a coordinate system among the Agin Buryats associated with a better orientation on the horizontal plane. 
Хозяйственный уклад степных кочевников формировал у агинских бурят представление о системе координат, связанной с лучшей ориентацией на горизонтальной плоскости.

В то же время, мы выявили общую закономерность когнитивного функционирования у представителей всех коренных популяций, отличающую их от восточных славян - сниженную подвижность психических процессов, которая проявляется в сниженной скорости обработки информации. Так, при выполнении методики Кодирование дети коренных народов Сибири, в сравнении с восточными славянами, обработали меньшее количество знаков: якуты в среднем на 6,5 знака меньше $(\mathrm{p}<0,001)$, эвенки и эвены на $13,2(\mathrm{p}<0,001)$, алтайцы на $4,1(\mathrm{p}=0,001)$, тувинцы на $3,9(\mathrm{p}=0,003)$, агинские буряты на 1,9 знака $(\mathrm{p}=0,03)$.

Недавние нейропсихологические исследования показывают, что скорость обработки информации может быть важным индикатором в оценке риска самоубийства, так как является одной из функций когнитивной исполнительной системы, отвечающей за оценку меняющихся альтернатив и выполнение планов [3]. Данная функция связана с подвижностью протекания психических процессов и является характеристикой динамического компонента мышления.

Подвижность психических процессов в определённой степени может служить одним из показателей темперамента, так как отражает типологические свойства высшей нервной деятельности или нейродинамическое соотношение коры и подкорки [34]. Сниженную подвижность психических процессов у представителей коренных этносов мы объясняем длительным проживанием в суровом климате, что подчиняло весь образ жизни господствующим условиям сибирской природы, делая его неспешным и менее энергозатратным. Однако в новых социальных условиях низкая подвижность психических процессов может быть фактором риска суицидального поведения.

Данное исследование объясняет причину высокого уровня самоубийств у коренных народов Сибири с позиции когнитивного подхода. Однако для более глубокого понимания механизмов формирования суицидального поведения требуется продолжение дальнейших исследований нейрокогнитивных функций и их связи с суицидом.

\section{Выводы:}

Становление операционального интеллекта у представителей всех популяций происходит в соответствии с общими законами онтогенетического развития. Базовые психические функции являются универсальными для всех этнических групп, но могут приобретать черты культурной специфики вследствие влияния средовых факторов и особенностей традиционного образа жизни.

У представителей коренных народов Сибири, в сравнении с восточными славянами, выявлены культурно-специфические особенности когнитивных функ-
At the same time, we revealed a general pattern of cognitive functioning among representatives of all indigenous populations that distinguishes them from the Eastern Slavs - a reduced mobility of mental processes, which manifests itself in a reduced information processing speed. So, when performing the Coding methodology, the indigenous children of Siberia compared to the Eastern Slavs, processed a smaller number of characters: the Yakuts, on average, are 6.5 characters behind $(\mathrm{p}<0.001)$, Evenks and Evens are 13.2 characters behind $(p<0.001)$, Altaians are 4.1 characters behind $(\mathrm{p}=0.001)$, Tuvans are 3.9 characters behind $(\mathrm{p}=0.003)$, Agin Buryats are 1.9 characters behind $(p=0.03)$. Recent neuropsychological studies show that information processing speed can be an important indicator in assessing suicide risk, as it is one of the functions of the cognitive executive system that is believed to be responsible for assessing changing alternatives and fulfilling plans [3]. This function is associated with the mobility of the course of mental processes and is a characteristic of the dynamic component of thinking. The mobility of mental processes to a certain extent can serve as one of the indicators of temperament, as it reflects the typological properties of higher nervous activity or the neurodynamic ratio of the cortex and subcortex [34].

We explain the reduced mobility of mental processes among representatives of indigenous ethnic groups by prolonged living in harsh climate that makes the entire way of life subject to the dominating conditions of Siberian nature, making it less quick and more energy-saving. However, under the new social conditions, low mobility of mental processes may be considered a risk factor for suicidal behavior. This study explains the reason for the high suicide rate among the indigenous peoples of Siberia from the perspective of a cognitive approach. However, a deeper understanding of the mechanisms of formation of suicidal behavior requires the continuation of further studies of neurocognitive functions and their relationship with suicide.

Conclusion:

The formation of operational intelligence in representatives of all populations occurs in accordance with the general laws of ontogenetic development. Though basic mental functions are universal for all ethnic groups, they can be affected by cultural specifics such as environmental factors and traditional way of life features.

Representatives of the indigenous peoples of Siberia, in comparison to the Eastern Slavs, revealed cultural-specific features of cognitive 
ций - сниженная скорость обработки информации, что мы расцениваем как нейрокогнитивный фактор риска суицидального поведения.

\section{Литература / Reference:}

1. Dixon-Gordon K.L., Gratz K.L., McDermott M.J., et al. The role of executive attention in deliberate self-harm. Psychiatry Res. 2014; 15 (218): 113-117.

2. Sarkisian K.L., Van Hulle C.A., Goldsmith H. Brooding, Inattention, and Impulsivity as Predictors of Adolescent Suicidal Ideation. J. Abnorm. Child. Psychol. 2019; 47 (2): 333-344.

3. Saffer B., Klonsky E.D. Does neurocognitive functioning distinguish suicide attempters from suicide ideators? A systematic review / International Summit on Suicide Research / New Horizons for Suicide Research: From Genes to Communities / Nevada, 2017. P. 111.

4. Keilp J.G., Sackeim H.A., Brodsky B.S., et al. Neuropsychological dysfunction in depressed suicide attempters. Am. J. Psychiatry. 2001; 158: 735-741.

5. King D.A., Conwell Y., Cox C., et al. A neuropsychological comparison of depressed suicide attempters and nonattempters. $J$. Neuropsychiatry Clin. Neurosci. 2000; 12: 64-70.

6. Marzuk P.M., Hartwell N., Leon A.C., et al. Executive functioning in depressed patients with suicidal ideation. Acta Psychiatr. Scand 2005; 112: 294-301.

7. McGirr A., Dombrovski A.Y., Butters M.A., et al. Deterministic learning and attempted suicide among older depressed individuals: cognitive assessment using the Wisconsin card sorting task. J. Psychiatr. Res. 2012; 46: 226-232.

8. Kaschka W.P., Rujescu D. Biological Aspects of Suicidal Behavior. Adv. Biol. Psychiatry. 2016; 30: 88-100.

9. Richard-Devantoy S., Olie E., Guillaume S., et al. Distinct alterations in valuebased decision-making and cognitive control in suicide attempters: toward a dual neurocognitive model. J. Affect. Disord. 2013; 151: 1120-1124.

10. Dombrovski A.Y., Clark L., Siegle G.J., et al. Reward/punishment reversal learning in older suicide attempters. Am. J. Psychiatry. 2010; 167: 699-707.

11. Keilp J.G., Beers S.R., Burke A.K., et al. Neuropsychological deficits in past suicide attempters with varying levels of depression severity. Psychol. Med. 2014; 44 (14): 2965-2974.

12. LeGris J., van Reekum R. The neuropsychological correlates of borderline personality disorder and suicidal behavior. Can. J. Psychiatry. 2006; 51 (3): 131-142.

13. Sheftall A., Brent D., Keilp J., et al. Neurocognitive functioning and aggression in mothers of adolescent suicide attempters. International Summit on Suicide Research / New Horizons for Suicide Research: From Genes to Communities / Nevada, 2017. P.113.

14. Keilp J., Beers S., Gorlyn M., et al. Neurocognitive deficits as familial risk factors for suicidal behavior / International Summit on Suicide Research / New Horizons for Suicide Research: From Genes to Communities / Nevada, 2017. P.111.

15. Brick L.A., Marraccini M.E., Micalizzi L., et al. Overlapping genetic effects between suicidal ideation and neurocognitive functioning. J. Affect. Disord. 2019; 15 (249): 104-111.

16. Chesin M., Mayers J., Cascardi M. Cognitive-affective correlates of suicide ideation and attempt among college students / International Summit on Suicide Research / New Horizons for Suicide Research: From Genes to Communities / Nevada, 2017. P. 202-203. functions - reduced processing speed that we regard as a neurocognitive risk factor for suicidal behavior.

17. Richard-Devantoy S., Gorwood P., Annweiler C., et al. Suicidal behaviours in affective disorders: a deficit of cognitive inhibition? Can. J. Psychiatry. 2012; 57: 254-262.

18. Jollant F., Bellivier F., Leboyer M., et al. Impaired decision making in suicide attempters. Am. J. Psychiatry. 2005; 162: 304-310.

19. Miranda R., Gallagher M., Bauchner B., et al. Cognitive inflexibility as a prospective predictor of suicidal ideation among young adults with a suicide attempt history. Depress. Anxiety. 2012; 29: $180-186$.

20. vanHeeringen K. Suicide and the connectome / International Summit on Suicide Research / New Horizons for Suicide Research: From Genes to Communities / Nevada, 2017. P. 16.

21. Hawton K., van Heeringen K. Suicide. Lancet. 2009; 373 (9672): 1372-1381.

22. vanHeeringen K. Stress-diathesis model of suicidal behavior. The neurobiological basis of suicide / Taylor \& Francis; 2012. Chap. 6.

23. King C.A., Merchant C.R. Social and Interpersonal Factors Relating to Adolescent Suicidality: A Review of the Literature. Arch. Suicide Res. 2008; 12 (3): 181-196.

24. Анастази А. Психологическое тестирование. СПб.: Питер, 2001. [Anastasi A. Psychological testing. SPb.: Peter, 2001.] (In Russ)

25. Otis, A. S., Lennon R.T., Otis-Lennon School Ability Test (OLSAT) technical manual. San Antonio, TX: Harcourt Brace. Educational Measurement, 1997.

26. Силвер Р., Копытин А.И. Рисуночный тест Р. Силвер Методическое руководство. СПб.: ИМАТОН, 2002. [Silver R. Kopytin A. I. Drawing test R. Silver: Methodological guidance. SPb.: Imaton, 2002.] (In Russ)

27. Венгер А.Л. Психологические рисуночные тесты. М.: ВЛАДОС, 2003. [Wenger A. L. Psychological drawing tests. Moscow: VLADOS, 2003.] (In Russ)

28. Triandis H.S., Eunkook M.S., Cultural influences on Personality. Annu. Rev. Psychol. 2002; 53: 133-160.

29. Piaget J. The Psychology of the Child. N.Y.: Grossman, 1969.

30. Fried P.J., Rushmore III R.J., Moss M.B. et al. Causal evidence supporting functional dissociation of verbal and spatial working memory in the human dorsolateral prefrontal cortex. Eur. J. Neurosci. 2014; 39: 1973-1981.

31. Семенова Н.Б. Когнитивные факторы риска суицидального поведения у коренных народов Севера. Суицидология. 2013; 4 (1): 28-32. [Semenova N.B. Cognitive risk factors for suicidal behavior among indigenous peoples of the North. Suicidology. 2013; 4 (1): 28-32.] (In Russ)

32. Семенова Н.Б. Особенности познавательной сферы детей коренных народов Севера. Вопросы психологии. 2015; 4: 5969. [Semenova N.B. Features of the cognitive sphere of children of indigenous peoples of the North. Question of psychology. 2015; 4: 59-69.] (In Russ)

33. Семенова Н.Б. Характеристика когнитивных функций у детей тувинцев: этнические и территориальные различия. Вопросы психологии. 2015; 6: 18-27. [Semenova N.B. Characteristics of cognitive functions in Tuvan children: ethnic and territorial differences. Question of psychology. 2015; 6: 1827.] (In Russ)

34. Рубинштейн С.Л. Основы общей психологии. СПб.: Питер, 2002. [Rubinstein S. L. Fundamentals of General psychology. $\mathrm{SPb}$. : Peter, 2002.] (In Russ)

\section{PREREQUISITES OF SUICIDAL BEHAVIOR IN CHILDREN AND ADOLESCENTS OF INDIGENOUS PEOPLES OF SIBERIA: COGNITIVE RISK FACTORS (PART II)}

\section{N.B. Semenova}

Federal Research Centre "Krasnoyarsk Scientific Centre of Siberian Division of Russian Academy of Sciences, Scientific Research Institute for Medical Problems of the North, Krasnoyarsk, Russia; snb237@gmail.com

\section{Abstract:}

Introduction. Cognitive risk factors for suicidal behavior were revealed in adolescents of Siberian indigenous peoples: dysfunctional attitudes, a tendency to excessive generalization, a subjective feeling of insolubility of life's difficulties. However, the importance of cognitive factors in the formation of suicidal behavior is not limited to a distorted cognitive scheme, but covers a wider range of mental processes. Aim of the study is to study the features of cognitive processes in indigenous populations of Siberia (Yakuts, Evens, Evenks, Altai, Agin Buryats and Tuvans), 
in comparison with the Eastern Slavs. The object of the study and research methods. The children of 9-10 years of age, the students of secondary schools living in rural areas, in the national subjects of the Russian Federation, a total number of 779 people were examined. Among them there are 180 Yakuts, 49 Evens and Evenks, 135 Altai, 154 Agin and Buryats, 98 Tuvinians, 163 Slavs from the East. The mean age was 9.8 y.o. The study used non-verbal methods: 1) Classification of pictures from the Otis-Lennon School Ability Test (OLSAT); 2) subtests: The concept of sequential order, the Concept of horizontality and the Concept of verticality from the battery of pictures of tests by R. Silver; 3) test The picture of a Man in the interpretation of A.L. Wenger; 4) methods: Reproduction of digital series, Battery coding of non-verbal subtests by D. Wechsler (WAIS, subtests V and VII). Statistical processing was performed using IBM SPSS Statistics, Version 22. Results. The formation of intellectual functions in representatives of different populations occurs in accordance with the general laws of ontogenetic development. The interpopulation differences that were identified relate to visual skills, memory indicators, the formation of ideas about the coordinate system and speed in processing information. In Yakuts, Evens, and Evenks, visual memory is better developed $(\mathrm{p}<0.001)$, compared to auditory memory. Tuvinians have better developed auditory and verbal memory, spatial thinking and the concept of vertical $(\mathrm{p}<0.001)$. The Buryats have better developed spatial thinking and horizontal understanding $(\mathrm{p}=0.03)$. Altai people have lower indicators of auditory-verbal memory $(\mathrm{p}=0.001)$. We explain these differences by the specifics of lifestyle and the main activities formed by unique natural landscapes of habitat. The main feature of cognitive processes among indigenous peoples, in comparison with the Eastern Slavs, is associated with different speed of information processing. When performing the Coding methodology, the Yakuts processed 22.3 characters; Evenks and Evens - 16.1; Altai - 26.2; Tuvans - 26.4; Agin Buryats - 28.4, which is lower compared to the Eastern Slavs (30.6 characters), $\mathrm{p}<0.001$. Conclusion. Representatives of the indigenous populations of Siberia, in comparison with the Eastern Slavs, revealed culturally specific features of cognitive functions - a reduced processing speed of information, which we consider as a risk factor for suicidal behavior associated with the characteristics of neurocognitive functioning.

Keywords: ethnopsychology, adolescents, children, mental health, suicide, indigenous peoples, Siberia, risk factors, neurocognitive functions.

Благодарности. Автор выражает огромную благодарность за помощь в организации экспедиционных исследований директору РЦ ПМСС Республики Саха (Якутия) (РС (Я)), заслуженному работнику образования РС (Я) В.Н. Филиппову и его заместителю по учебнометодической работе, почетному работнику образования РФ Т.Ф. Мартыновой; работникам администрации Агинского Бурятского округа Забайкальского края в лице консультанта отдела соц. развития С.Б. Базарова и зам. начальника отдела соц. развития Р.М. Балдоржиевой; начальнику отдела образовательной политики Министерства образования и науки Республики Алтай О.С. Саврасовой.

Автор благодарит за помощь в проведении исследований работников образования и здравоохранения РС (Я): зав. отделом инновационных технологий РЦ ПМСС Мин. Обр. РС(Я) Р.Н. Андрееву; зав. РПМПК РЦ ПМСС Мин. Обр. РС (Я) И.И. Андрееву; педагоговпсихологов РЦ ПМСС Мин. Обр. РС (Я) Е.Н. Семенову, А.Ф. Петрову и А.Н. Андросову; специалиста управления образованием Олекминского района Н.С. Макарову; врача психиатра ГУ ЯРПНД Мин. Здрав. РС (Я) Е.В. Мордосову; врача педиатра ЦБ Усть-Майского улуса Ю.Е. Ноеву; врачей психиатров РПМПК РЦ ПМСС Мин. Обр. РС (Я) Т.Н. Саввину и Т.С. Сивцеву.

Автор благодарен за помощь в сборе и обработке полученного материала научным сотрудникам ФИЦ КНЦ СО РАН, г. Красноярска: в.н.с., к.м.н. В.А. Вшивкову, в.н.с., к.м.н. А.Ю. Холомеевой; в.н.с., к.м.н. Л.В. Лаптевой; н.с. Н.Г. Муравьевой; медицинским психологам КГБУЗ ККПНД №1 А.Ф. Музафаровой, Е.Е. Долгушиной, Ю.Н. Орловой.

Gratitude. The author is highly grateful for the help in organizing expeditionary research to the Director of the Primary Medical Center of the Republic of Sakha (Yakutia), Honored Worker of Education of the Sakha Republic, Yakutia V.N. Filippov and his deputy for educational and methodical work, honorary worker of education of the Russian Federation, excellent representative of education of the Sakha Republic, Yakutia T.F. Martynova; employees of the administration of the Aginsky Buryat district of the Transbaikal Territory and its representatives - a consultant of the department of social development S.B. Bazarova and the Deputy Head of Social Development R.M. Baldorzhieva; the Head of the Educational Policy Department of the Ministry of Education and Science of the Republic of Altai O.S. Savrasova.

The author is grateful for the help in conducting research on education workers and health workers of the Republic of Sakha (Yakutia): Department of Innovative Technologies of Republican Center for Psychological, Medical and Social Support R.N. Andreev; the Deputy Head of the Republican Center for Psychological, Medical and Social Support I.I. Andreev; to the teaching psychologists of the Republican Center for Psychological, Medical and Social Support E.N. Semenov, A.F. Petrov and A.N. Androsov; Education Management Specialist of the Olekminsky District N.S. Makarov; psychiatrist at the Yakut Republican Neuropsychiatric Dispensary E.V. Mordosov; pediatrician of the Central Bank of Ust-May ulus Yu.E. Noah, psychiatrists of the Republican Center for Psychological, Medical and Social Support T.N. Savvina and T.S. Sivtseva.

The author is grateful for the help in collecting and processing the obtained material to the scientific staff of the Krasnoyarsk Scientific Center of the Siberian Branch of the Russian Academy of Sciences, Krasnoyarsk: V.A. Vshivkov, senior researcher, candidate of medical sciences A.Yu. Kholomeeva; Senior Researcher, Ph.D. L.V. Lapteva; n.s. N.G. Ant; medical psychologists Krasnoyarsk Regional Psychoneurological Dispensary №1 A.F. Muzafarova, E.E. Dolgushina, Yu.N. Orlova.

Финансирование: Данное исследование не имело финансовой поддержки.

Financing: The study was performed without external funding.

Конфмикт интересов: Автор заявцяет об отсутствии конфиикта интересов.

Conflict of interest: The author declare no conflict of interest.

Статья поступима / Article received: 21.06.2019. Принята к пубмикации / Accepted for publication: 18.10.2019.

Для цитирования: Семёнова Н.Б. Предпосылки суицидального поведения у детей и подростков коренных народов Сибири: когнитивные факторы риска (часть II). 2019; 10 (3): 19-31. doi.org/10.32878/suiciderus.19-10-03(36)-19-31

For citation: $\quad$ Semenova N.B. Prerequisites of suicidal behavior in children and adolescents of indigenous peoples of Siberia: cognitive risk factors (part II). Suicidology. 2019; 10 (3): 19-31. (In Russ)

doi.org/10.32878/suiciderus.19-10-03(36)-19-31 